\title{
Menials or managers? A decade of library and information science education at the Cape Technikon
}

\author{
E.S. van Aswegen \\ Department of Library and Information Studies, School of Teacher Education, Cape Technikon, P.O. Box 652, Cape Town \\ 8000 Republic of South Africa \\ lizvanas@edutech.ctech.ac.za
}

\begin{abstract}
This article gives a survey of the first decade of education of library and information science workers at technikons in South Africa, with particular reference to the Cape Technikon. The development of a variety of qualifications is sketched, culminating in the introduction of degrees in 1996. The introduction of technikon library and information science qualifications at a time when rationalization of programmes at universities was introduced, as well as the uncertainty regarding the status of technikon diplomates is discussed. In conclusion, the impact of the National Commission on Higher Education policy, as well as the implementation of a National Qualifications Framework, is briefly addressed.

Hierdie artikel bied 'n oorsig van die eerste dekade van opleiding van biblioteek- en inligtingwerkers aan technikons in Suid-Afrika, met besondere verwysing na die Kaapse Technikon. Die ontwikkeling van 'n verskeidenheid kwalifikasies, wat gekulmineer het in die instelling van grade in 1996, word geskets. Die instelling van technikonbiblioteek- en inligtingkunde-kwalifikasies gedurende die tydperk van rasionalisasie van onderrigprogramme aan universiteite word aangeraak, sowel as die onsekerheid met betrekking tot die status van technikonafgestudeerdes. Ten slotte word die impak van die beleid van die Nasionale Kommissie oor Hoër Onderwys, sowel as die implementering van 'n Nasionale Kwalifikasieraamwerk, kortliks bespreek.
\end{abstract}

The education and training of librarians in South Africa was initially undertaken by the South African Library Association (SALA) in 1933, following the recommendations of the Carnegie Corporation commissioners, Messrs Ferguson and Pitt, in 1928. SALA followed the British model of correspondence courses, which continued until 1962 (Musiker, 1986:91), when its courses were transferred to the University of South Africa (Lessing, 1991:124). At its Grahamstown Conference, it was decided that the last examinations would be conducted in December 1965. However, SALA would continue to assist, inter alia, in the training of Non-White library workers (Van Rooy, 1966; Lessing, 1987:285). ${ }^{1}$

\section{University education and training}

According to Musiker (1986:91), the University of Pretoria was the first to offer training for librarians in 1938, followed by the University of Cape Town in 1939. The University of South Africa commenced its courses in 1955, followed by Potchefstroom University for Christian Higher Education in 1956; the University of Stellenbosch and the University of the Witwatersrand in 1958; the University of the Orange Free State in 1964; Rhodes University in 1966; the Rand Afrikaans University in 1968; and the University of Natal (Pietermaritzburg), the University of Fort Hare, the University of Durban-Westville, the University of Zululand, the University of the North, the University of the Western Cape and the University of Transkei, in 1973. The South African Institute for Librarianship and Information Science (the reconstituted SALA) continued its involvement in education through its Standing Committee for Formal Education.

The university qualifications (excluding specialist qualifications for school librarians), were a two-year postmatriculation Lower Diploma in Librarianship, a one-year post-graduate Higher Diploma in Librarianship, or a four- year professional bachelor's degree (the $\mathrm{BABibl),} \mathrm{later} \mathrm{to}$ become the BBibl.

\section{Professional, paraprofessional, semiprofessional, clerical}

The aim of the four-year university qualification was seen as 'preparation for professional duties in library and information services' (Musiker, 1986:92), while that of the two-year lower diploma was designated as the preparation of paraprofessional or semiprofessional workers, namely 'preparation for routine technical duties in library and information services' (Musiker, 1986:92). In addition, libraries have traditionally had numerous 'non-professional' posts, which in practice have encompassed a wide variety of positions, ranging from clerical and technical staff, to graduates in possession of, for example, bachelors' degrees or teaching qualifications. Various library activities and tasks were defined as being either 'professional' or 'paraprofessional/semiprofessional' (see Le Roux, 1985; South African Institute for Library and Information Science [SAILIS], 1987; Meijer $e t$ al., 1988). In addition, the SAILIS Committee for Formal Education has been active in devising guidelines for undergraduate career training, in which a distinction is made between professional and paraprofessional qualifications. (See Proposed guidelines for undergraduate career training, SAILIS, 1996:1179-1193.)

\section{Technikon education and training}

By the late 1970s and early 1980s the education of para- or semiprofessionals by means of the university Lower Diploma was phased out by most universities as being courses of subdegree standard (Kerkham, 1988:7). The demise of the twoyear Lower Diploma in Library and Information Science 
(LIS), ${ }^{2}$ and the subsequent development of the three-year National Diploma in Library and Information Services offered by technikons, has been chronicled at length by Kerkham (1988:8-9). In the event, Port Elizabeth Technikon commenced with a group of part-time students in 1984, followed by the Cape Technikon in 1985, Pretoria Technikon and M.L. Sultan Technikon in 1986, and for a brief period only, Natal Technikon in 1987. Technikon Southern Africa started a correspondence National Diploma aimed at recruiting LIS workers already employed in libraries but without any formal qualifications in 1992.

\section{Bunting report}

A subsequent factor affecting departments of library and information science at universities was the attempt made by the Academic Planning Committee (APC) of the Committee of University Principals (CUP), to rationalize the offering of courses in librarianship and information science at universities. According to Bunting (1990:58), by 1987, 13 universities were offering formal programmes in librarianship/ information science. In 1989 there were 11 fully active departments, Rhodes and Durban-Westville having closed. The next 'casualty' was to be the University of the Witwatersrand in the early 1990s.

The review committee formulated the following conclusions:

- that librarianship programmes are not cost effective;

- that unnecessary duplication exists in the teaching of librarianship in universities;

- that librarianship programmes in the residential universities are underutilized; and

- that the overall quality of librarianship programmes is not good (Bunting, 1990:63).

The review committee's view was that librarianship programmes could be rationalized as follows:

- by closing specific departments of librarianship;

- by placing a ceiling or limit on the formal qualifications that departments of librarianship may offer;

- by intra-university co-operation (e.g. by linking the departments of librarianship with other academic departments and service units such as central libraries);

- by merging or amalgamating departments of librarianship with other departments or academic units;

- by placing a limit on the specialized fields in which departments of librarianship may operate; and

- by interuniversity co-operation (e.g. by the sharing between universities of courses and of academic staff members) (Bunting, 1990:65).

Not all universities heeded the recommendations of the Bunting report (inter alia that lower diplomas should be phased out by universities and offered by technikons). However the University of Stellenbosch consequently phased out post-graduate degrees after honours level.

The four-year BBibl is currently offered by the University of the Orange Free State, the University of Pretoria, the University of Stellenbosch, the University of Fort Hare, the
University of the North, the University of the Western Cape, the University of Zululand, Potchefstroom University for C.H.E., the Rand Afrikaans University and the University of South Africa.

The Postgraduate Diploma/Higher Diploma in Library and Information Science (nomenclature varies) is offered at the University of Cape Town, Rand Afrikaans University, the University of Natal, the University of the North and the University of Zululand.

\section{Problems regarding the status of technikon grad- uates}

The National Diploma in Library and Information Services at technikons was in its infancy at the height of the Bunting debacle, resulting in recriminations from universities whose departments of LIS were threatened with closure. From its very inception, there had been problems regarding the status of technikon 'diplomates'. Although the National Diploma in Library and Information Services was evaluated by the Human Sciences Research Council as 'Senior Certificate plus three years' training in Library and Information Services' (Kerkham, 1988:9), and consequently

'recognized as being on a par with any other National

Diploma ... diplomates ... therefore appointed on the same rank and salary scale as other technicians with National Diplomas in art, horticulture, chemistry, engineering, etc',

most libraries had no separately designated post descriptions for LIS technikon diplomates, and technikon-educated employees found themselves working 'below stairs' as it were, on a par with library assistants in possession of a senior certificate, with one or two salary notches to compensate for three years training, and few prospects of promotion beyond that of senior library assistant. However in 1986, two new Technikon Port Elizabeth graduates (admittedly with library experience), ${ }^{3}$ were appointed to professional posts as heads of special libraries in the Western Cape. By and large, however, technikon diplomates found themselves too highly qualified for most of the fairly menial and routine tasks which they were allocated, but not qualified enough to be appointed full professionals. An alumni survey done by the Department of Library and Information Studies at the Cape Technikon of 1987-1991 graduates (with 23 alumni responding), revealed the following information (see Table 1).

One student did not rate the diploma, since she had married and had not been employed in a library. Alumni were requested to substantiate their rating with a written comment, and the most negative remarks pertained to the library and information community's reluctance to accept the qualification, employers not having post descriptions and salary structures to accommodate the qualification, as well as the profession's perception of what professionalism in library and information science entailed. The most prevalent complaint was that diplomates were allocated the same menial tasks as library assistants with a senior certificate, and that areas such as cataloguing (in which diplomates had received two years 


\begin{tabular}{l} 
Table 1 Departmental \\
questionnaire to alumni \\
$1987-1991$ \\
\hline With regard to your experience in \\
the work situation, rate the Na- \\
tional Diploma in Library and In- \\
formation Services (academic and \\
co-operative education) on a scale \\
of 1 to 5 (5 = excellent; $3=$ aver- \\
age; $1=$ useless). \\
\hline Rating \\
\hline 5 \\
4 \\
3
\end{tabular}

of training), were considered the sacrosanct bailiwick of the professional librarian.

\section{Term 'paraprofessionalism'}

A further problem arose with the term paraprofessionalism as 'an alternative career direction, not an inferior career direction ... a parallel career direction; ... not per se a step in the direction of professionalism' (Kerkham, 1988:8).

The well-worn analogies of doctors versus nurses, radiographers, medical technicians, social workers and pharmacists, not to mention ophthalmologists and optometrists, dentists and dental technicians, engineers and engineering technicians did not operate in the South African library and information environment. Furthermore, the designation 'library technician', although well established in the USA and Canada, was alien to the South African LIS community, conjuring up an invasion of grease-stained 'rude mechanicals', who were qualified only to operate the photocopier! A further complication was the confusion in the public mind between technikons (institutions providing vocational education at tertiary level up to 6 years post-matric) and technical colleges (providing technical/vocational education and training ( $\mathrm{N}$-courses) from Std 8 up to one year's post-matric).

\section{Professional status}

To obtain 'professional' positions in most libraries, technikon diplomates, therefore, had no option but to enrol for a BBibl, or BA plus post-graduate diploma at a university. Although most universities were willing to give some credits in the case of professional library and information subjects, the full number of extra professional credits for a first degree still had to be completed. The much vaunted possibilities of 'articulation' or mobility between technikons and universities, a major talking point during the early days of technikon education (Shippey, 1983/84; ALISER, 1992) had not come to fruition. In a study of the development of higher education in California during the last 25 years, Prof T.C. Shippey (1983/84:19), Rector of the Cape Technikon, wrote as follows:

'Another essential element which is strongly present in California but is lacking in South Africa is student mobility and accreditation from one higher education sector to another. In California careful provision is made for articulation relating to accreditation and many students move freely from CCS (the junior colleges, now known as community colleges) to the UC (the University of California) or CSU (the California State University) systems. As long as they have complied with accreditation requirements which are set out in detail, then they can gain all or partial accreditation at all UC or CSU institutions for certain courses which they have completed at a CC or similar institution.

In South Africa limited accreditation (up to $50 \%$ generally) is the norm between universities, and university students moving to technikons can easily obtain a good measure of credit for completed courses. However, technikon or college of education students are given very few credits and some universities do not allow any accreditation from such institutions. Thus student mobility is greatly reduced and there is little inducement for technikon or college of education students to study further at a university. If such articulation and accreditation is possible among the far greater number of higher education institutions in California, then surely South Africa could attempt to bring about adjustments in its tertiary sector and break down some of the rigidity which exists.'

There are several examples of technikon diplomates who have spent seven years of study to achieve 'professional' qualifications (and in many cases acquitting themselves very well in their degree studies). Some students enrolled at universities with a view to obtaining a professional LIS qualification, but were diverted into other (more lucrative) professions, such as teaching, psychological counselling or even secretarial work. Figure 1 (Cape Technikon, 1995) disconcertingly depicts alumni in the fields of library and information science and education (the Department of Library and Information Studies resides under the School of Teacher Education at the Cape Technikon) as the lowest earners in all 11 Cape Technikon disciplines.

\section{SAILIS and SERTEC}

In 1988, the National Diploma: Library and Information Services at the Cape Technikon was evaluated and accredited as a paraprofessional diploma by SAILIS' Committee for Formal Education (to date the only technikon to have applied for accreditation). However, the modus operandi of the evaluating committee, as well as the report form for annual 


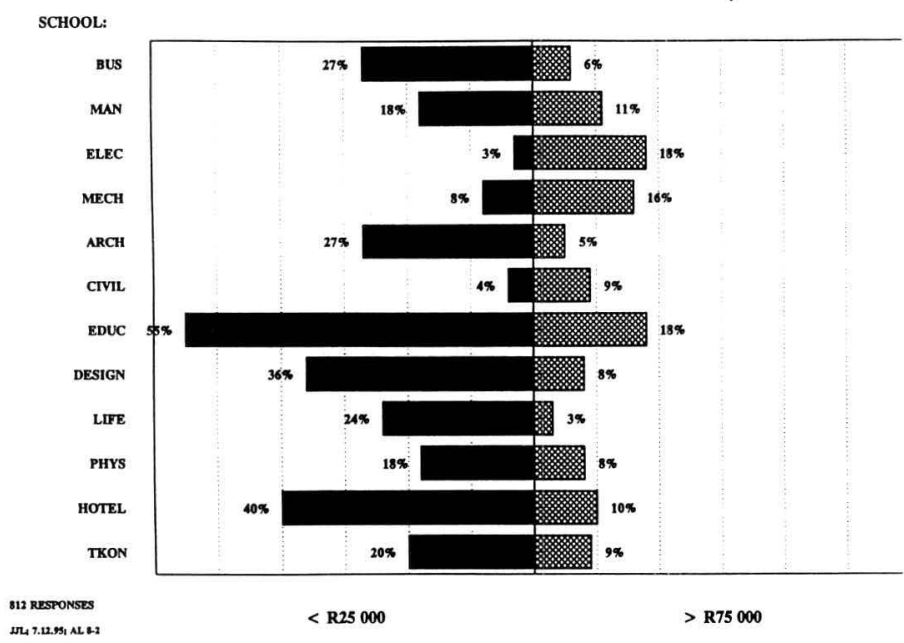

Figure 1 Alumni survey 1995: annual salary plus fringe benefits alumni who graduated since 1992

reports to SAILIS regarding the status of the teaching department, had not been revised to make provision for technikon structures. Some examples: technikon departments of LIS are not autonomous, like their university counterparts; the technikon's compulsory component of experiential training is much longer and more structured than the universities' field work components.

Some impetus towards the recognition of technikon diplomates as professionals was gained by SAILIS's revision of its conditions for professional membership (at the Esselen Park national conference in 1994). At the same time, technikons were under intense scrutiny by the Certification Council for Technikon Education (SERTEC), with evaluation and accreditation of the technikons' co-operative education (experiential training) LIS programmes being evaluated in 1991 and 1995, and the formal teaching LIS programmes in 1993.

\section{Degrees at technikons}

Technikons in South Africa, like their British and Australian counterparts, the polytechnics, were changing to degree granting institutions (the British polytechnics having become the new universities in the early 1990s). Technikon degrees were instituted in the early 1990s, and in January 1996 certain technikons were granted permission by SERTEC to offer the following additional LIS qualifications:

BTech: Library and Information Studies

MTech: Library and Information Studies

DTech: Library and Information Studies.

This once again involved radical recurriculation, with some technikons, given the large intake of students from previously disadvantaged communities, opting to offer the preliminary National Certificate $(M+1)$ and National Higher Certificate $(\mathrm{M}+2)$ also.

The original hierarchy of technikon qualifications, namely

$\begin{array}{ll}\text { National Diploma } & \mathrm{M}+3 \\ \text { National Higher Diploma } & \mathrm{M}+4 \\ \text { Master's Diploma in Technology } & \mathrm{M}+5 \\ \text { Laureatus in Technology } & \mathrm{M}+6\end{array}$

was therefore replaced by the Baccalaureus Technologiae (BTech): Library and Information Studies degree, followed by Master's and Doctoral degrees. Since its inception, the National Diploma in Library and Information Services had undergone radical recurriculation, with the revised National Diploma in Library and Information Practice superseding the National Diploma in Library and Information Services in 1992. 1996 saw the implementation of the National Diploma in Library and Information Studies (the second change in nomenclature since the inception of the diploma).

The current technikon hierarchy of qualifications is therefore:

- National Certificate: Library and Information Studies $(\mathrm{M}+1)$

- National Higher Certificate: Library and Information Studies $(\mathrm{M}+2)$

- National Diploma: Library and Information Studies $(\mathrm{M}+3)$

- BTech: Library and Information Studies $(M+4)$

- MTech: Library and Information Studies $(M+5)$

- DTech: Library and Information Studies $(M+6)$.

\section{Cape Technikon curricula}

The revised curricula for Library and Information Studies at the Cape Technikon (technikons follow the same basic curricula with options to meet local LIS needs and conditions) comprise the following:

\section{National Certificate: Library and Information Studies}

Library and Information Practice I

Information Retrieval I

Library and Information Technology I

End-User Computing I

Human Studies

Two of the 11 official languages, of which one must be English or Afrikaans.

National Higher Certificate: Library and Information Studies

Library and Information Practice II

Information Retrieval II

Library and Information Technology II

Literature Studies I

Psychology in Organizations I

Library Promotion I

\section{National Diploma: Library and Information Studies}

Library and Information Practice III

Information Retrieval III

Experiential training (six months' employment in a library) 


\section{BTech: Library and Information Studies}

Library and Information Practice IV

Information Retrieval IV

Research Methodology

Children's Library Practic

Book Conservation

Information Management

Readership Service to Semi-Literates

Philosophy of Library and Information Science

Students are allowed to choose three subjects out of the last five subjects.

\section{MTech: Library and Information Studies - advanced research}

DTech: Library and Information Studies- advanced research

Candidates therefore have the option of exiting with a semi/ paraprofessional qualification after one, two or three years of study. The Cape Technikon has opted not to offer the National Certificate and National Higher Certificate, but the National Diploma: Library and Information Studies and BTech: Library and Information Studies. Admission requirements for the BTech at the Cape Technikon are a minimum of $60 \%$ in each of the major final-year National Diploma subjects. The Cape Technikon has also been granted permission by SERTEC to offer the MTech: Library and Information Studies, as well as the DTech. No candidates are as yet registered for the higher research degrees.

\section{Current status of Cape Technikon alumni}

By the 1990s, Cape Technikon diplomates were employed in a wide variety of library and information service positions, in some cases as heads of special libraries or small public libraries. However, only a few libraries (inter alia the University of Stellenbosch Library Services and the South African Library) had pro-actively instituted special post designations such as Assistant Librarian and Professional Assistant to accommodate technikon graduates.

Kerkham (1988:10) correctly identifies professional librarians, to date, as having performed many routine technical tasks in user and technical services.

'However, with the increasing availability of trained library technicians, it should be possible for such tasks to be expertly performed by the paraprofessional. This will free the professional librarian to concentrate on professional aspects which require conceptual development and content analysis, such as building up collections, investigation of information needs, design and development of information systems, and evaluation of systems and services. In conclusion, it can be said that the advent of welltrained library technicians will be of great benefit to libraries and information services. Work of a technical nature will be expertly handled, and professional librarians will at last be freed to perform truly professional functions. Library technicians have an attractive career option with possibilities of advancement to supervisory appointments' .

The rosy future envisaged by Kerkham, has not been fulfilled. With the exception of corporate and special libraries, where technikon graduates with their superior computer and office management skills have found an expert niche, and some academic and national libraries, technikon graduates have, up to now, been forced to travel the long and expensive road of 're-education' at a university to obtain true professional status.

In spite of negativity and apathy on the part of much of the 'establishment' LIS community (Van Vuren [1995:723], in her seminal work, notes that 'werkgewers moet attent gemaak word daarop dat postestrukture aangepas behoort te word'), ${ }^{4}$ recent alumni surveys of LIS graduates (see Appendix A) ${ }^{5}$ at the Cape Technikon have been positive (Cape Technikon, 1995). The Department of Library and Information Studies was rated as one of the ten top performers at the Cape Technikon in the fields of experiential training (traditionally known as 'field work' at university departments of LIS), applicability of course content, overall experience of the technikon and technikon contribution to skills (see Figures 25 [CapeTechnikon, 1995]). The same survey (Cape Technikon, 1995), indicated that $76 \%$ of graduating students had found employment (Figure 6). However this survey was based only on questionnaire responses. A more accurate picture is obtained from an informal departmental survey of the 1995 ND: Library and Information Practice graduates, which revealed that by July 1996, $78.5 \%$ of all graduates of the class of 1995 had found employment in libraries. Altogether 22 students registered for the BTech: Library and Information Studies at the beginning of 1996 (offered parttime over two years); of these 22 students, only one is not employed in a library. One student in possession of a BBibl

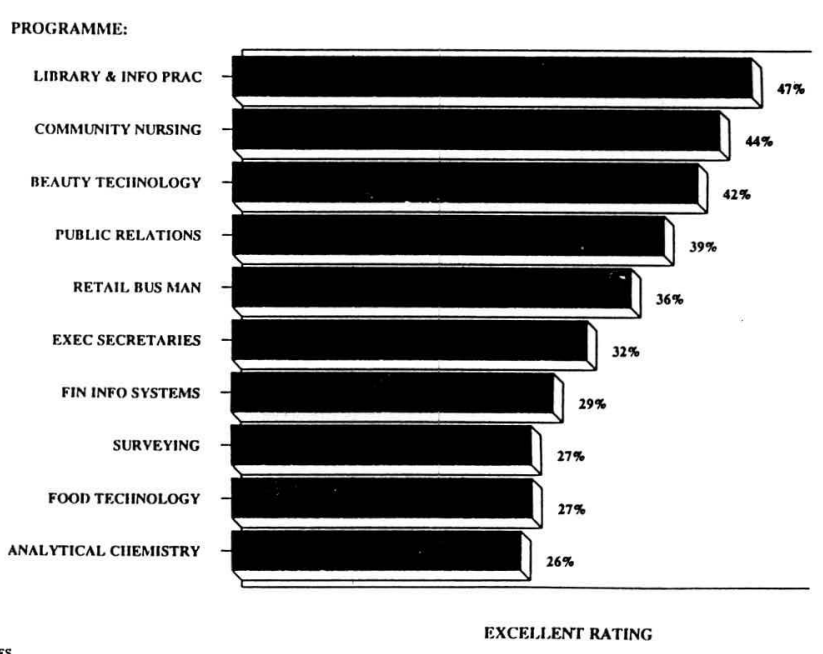

1591 RESPONSFS

Figure 2 Alumni survey 1995: experiental training - ten best performers 


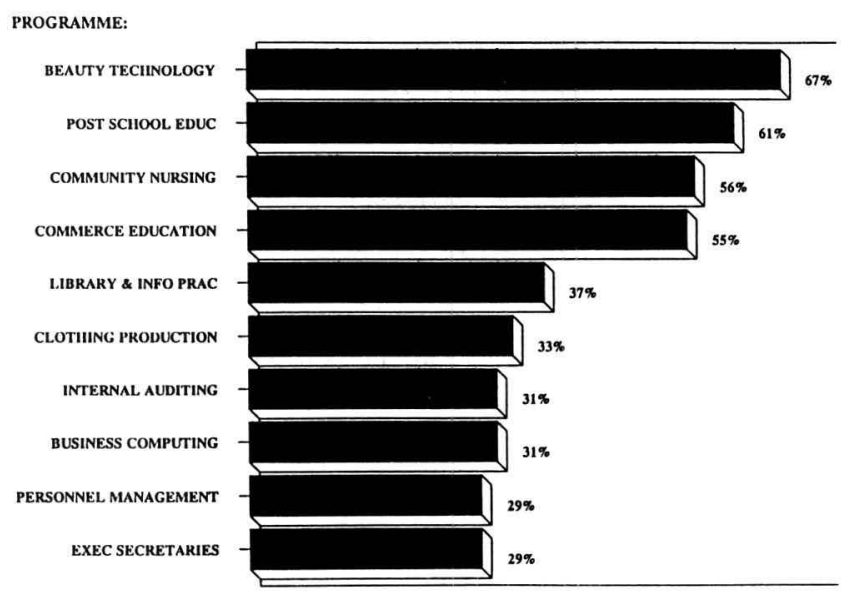

1391 RESPONSES

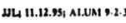

Figure 3 Alumni survey 1995: applicability of course content - ten best performers

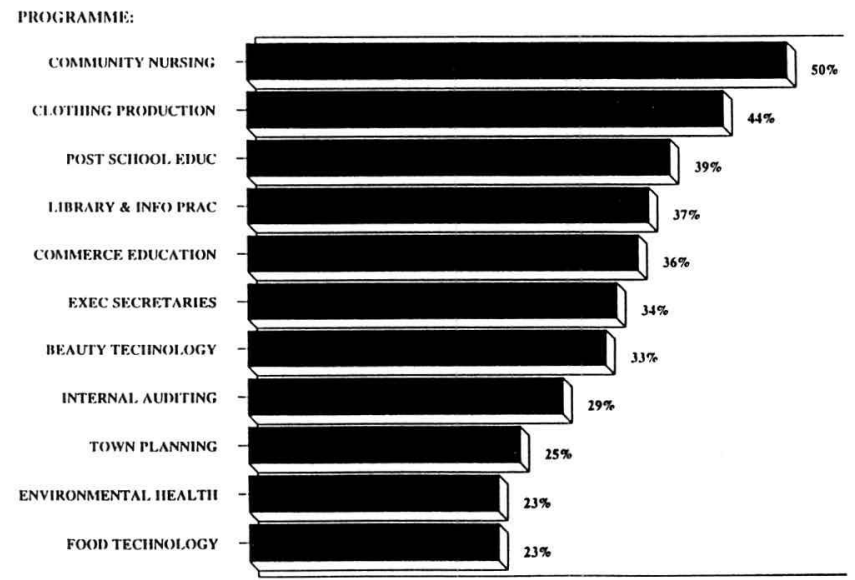

1591 RESTONSES

EXCEI.I.ENT RATING;

JI $11.12 .9 S_{i}$ AL.UN 9.2 .4

Figure 4 Alumni survey 1995: overall experience of Technikon ten best performers

has enrolled for the subject Research Methodology, with a view to enrolling for an MTech in 1997.

\section{Conclusion}

Over the past few decades attempts have been made to review the tertiary education scene in South Africa and to plan for the future. The Main Report of the Commission of Inquiry into Universities under the chairmanship of Mr Justice van Wyk de Vries, and the Human Sciences Research Council (HSRC) Report attempted to provide some framework for education for the end of the twentieth century. It is hoped that the National Commission of Higher Education's proposals for a new system of higher education, inter alia 'the development of a single co-ordinated system of higher education encompassing universities, technikons, colleges and private providers' (South Africa, National Commission on Higher Education, 1996:9) will facilitate mobility and accreditation.

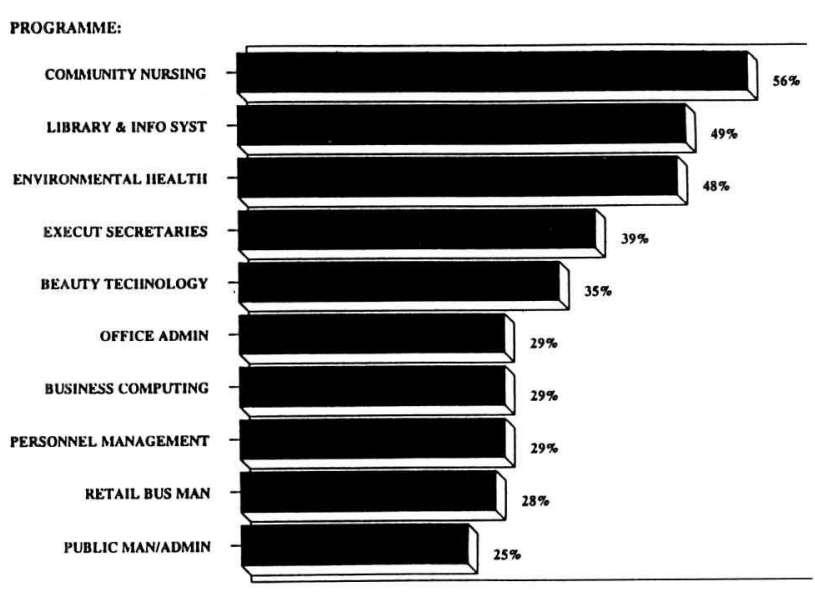

LARGE CONTRIBUTION

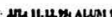

Figure 5 Alumni survey 1995: Technikon's contribution to skills ten best performers

PROGRAMME

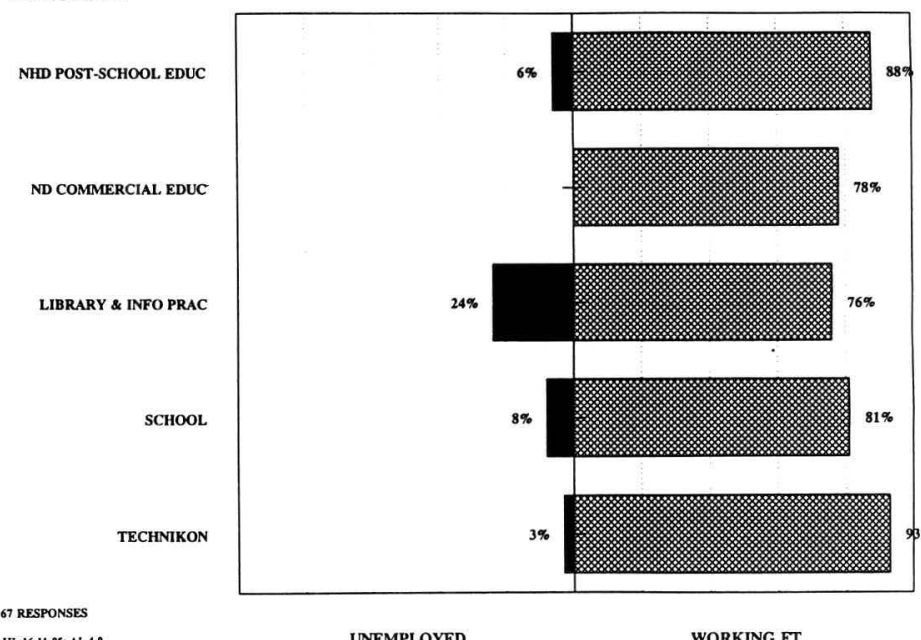

MLi6.11.95; AL 49

UNEMPLOYED

WORKING FT

Figure 6 Alumni survey 1995: employment status - School of Teacher Education

The current debate in education circles regarding National Vocational Qualifications (NVQ's) ${ }^{6}$ will no doubt add a further dimension to the education and training of LIS workers in South Africa. However, it is hoped that the implementation of degrees at technikons, and SAILIS' guarded acknowledgement of technikon degree programmes as admission to professional positions (SAILIS, 1996:1180) will herald a less conservative and more innovative approach to the education and training of LIS workers in South Africa.

\section{Disclaimer}

The views expressed in this article reflect the experiences of the author as Associate Director, Department of Library and Information Studies, at the Cape Technikon. Opinions and views expressed do not, therefore, necessarily reflect the views and experiences of other South African technikons offering LIS education and training. 


\section{Notes}

1. The author recalls tutoring Black library workers enrolled for SALA qualifications in 1969/1970.

2. The Lower Diploma in LIS is still offered by the University of the Western Cape (a three-year course), and the University of Fort Hare (a two-year course).

3. Personal correspondence with Ms Annemarie Greyling, Librarian, South African Cultural History Museum, Cape Town, and Ms Naomi Haasbroek, Senior Librarian, Scientific and Technical Library, National Accelerator Centre, Faure.

4. In a Delphi study, library and information managers were consistently more careful and conservative in their responses than mentors (middle managers) who completed the same questionnaire.

5. The questionnaire was mailed to all graduates of the class of 1995.

6. NVQ's are well established in the United Kingdom, especially in the hospitality trade. Their relevance to the LIS sector was addressed at the 1995 SAILIS Conference by Walker (1995) and at an address given to the SAILIS (Western Cape) Branch by Robert and Margaret Oldroyd (Oldroyd \& Oldroyd, 1996).

\section{References}

ASSOCIATION FOR LIBRARY AND INFORMATION SCIENCE EDUCATION AND RESEARCH (ALISER). 1992. 'Bye Baby

Bunting': papers delivered at a workshop on co-operation between library and information science educational institutions in the Western Cape in the Post-Bunting era, Wednesday 17 June 1992, Cape Town: Cape Technikon. (Unpublished).

BUNTING, I.A. 1990. Librarianship and the rationalisation of South African universities. In Nassimbeni, M. \& De Jager, K. (eds). The future of library and information science: social, technological and educational challenges. Proceedings of the 50th Anniversary Symposium of the School of Librarianship, 20-21 November 1989. Cape Town: University of Cape Town:53-66.

CAPE TECHNIKON. 1995. Profiles of the Cape Technikon. Cape Town: Cape Technikon.

KERKHAM, A.S. 1988. The education of library technicians in South Africa. South African journal of library and information science, 56(1):7-10.
LE ROUX, H.S. 1985. Guidelines for distinguishing between professional and non-professional work and staff in library and information services. Pretoria: South African Institute for Librarianship and Information Science, Committee for Education and Research.

LESSING, C.J.H. 1987. Die Suid-Afrikaanse Biblioteekvereniging en biblioteekopleiding in Suid-Afrika. Suid-Afrikaanse tydskrif vir biblioteek-en inligtingkunde, 55(4):277-289.

LESSING, C.J.H. 1991. Bydrae van die Suid-Afrikaanse Biblioteekvereniging (1930-1980) tot biblioteekontwikkeling in SuidAfrika. Suid-Afrikaanse tydskrif vir biblioteek-en inligtingkunde, 59(2):123-134.

MEIJER, J.G., BURGER, J.F., DU PREEZ, M. \& HAAG, D.E. 1988. Kurrikuleringsbeplanning vir biblioteek en inligtingkunde in Suid-Afrika. Verslag BIN-2. Pretoria: Raad vir Geesteswetenskaplike Navorsing.

MUSIKER, R. 1986. Companion to South African libraries. Craighall: Ad Donker.

OLDROYD, R. \& OLDROYD, M. 1996. National vocational qualifications in information and library services: the UK experience. Papers delivered at a SAILIS (Western Cape) Branch Meeting on Thursday, 4 July 1996, at the University of Cape Town. (Unpublished).

SHIPPEY, T.C. 1983/84. Higher education in California. Cape Technikon yearbook:5-19.

SOUTH AFRICA. NATIONAL COMMISSION ON HIGHER EDUCATION. 1996. An overview of a new policy framework for higher education transformation, 22 August 1996. (Press copy).

SOUTH AFRICAN INSTITUTE FOR LIBRARIANSHIP AND INFORMATION SCIENCE (SAILIS). 1987. Standards for education for library and information science. Updated edition. s.l.: The Institute.

SOUTH AFRICAN INSTITUTE FOR LIBRARIANSHIP AND INFORMATION SCIENCE (SAILIS). 1996. Proposed guidelines for undergraduate career training. Attachment to Notice of SAILIS Council Meeting, 1 September 1996: 1179_ 1193.

VAN ROOY, H.C. 1966. Die Suid-Afrikaanse Biblioteekvereniging en die toekoms. Suid-Afrikaanse biblioteke, 34(2):62-69.

VAN VUREN, A.J. 1995. Kwalifikasiestruktuur vir technikonopleiding in biblioteek- en inligtingkunde deur middel van afstandsonderrig. Johannesburg: Randse Afrikaanse Universiteit. (Ongepubliseerde D Bibl-proefskrif).

WALKER, C. 1995. National vocational qualifications for LIS workers: an introduction. Paper presented at the 1995 Conference of the South African Institute for Librarianship and Information Science (SAILIS), Cape Town, 18-22 September. (Unpublished). 

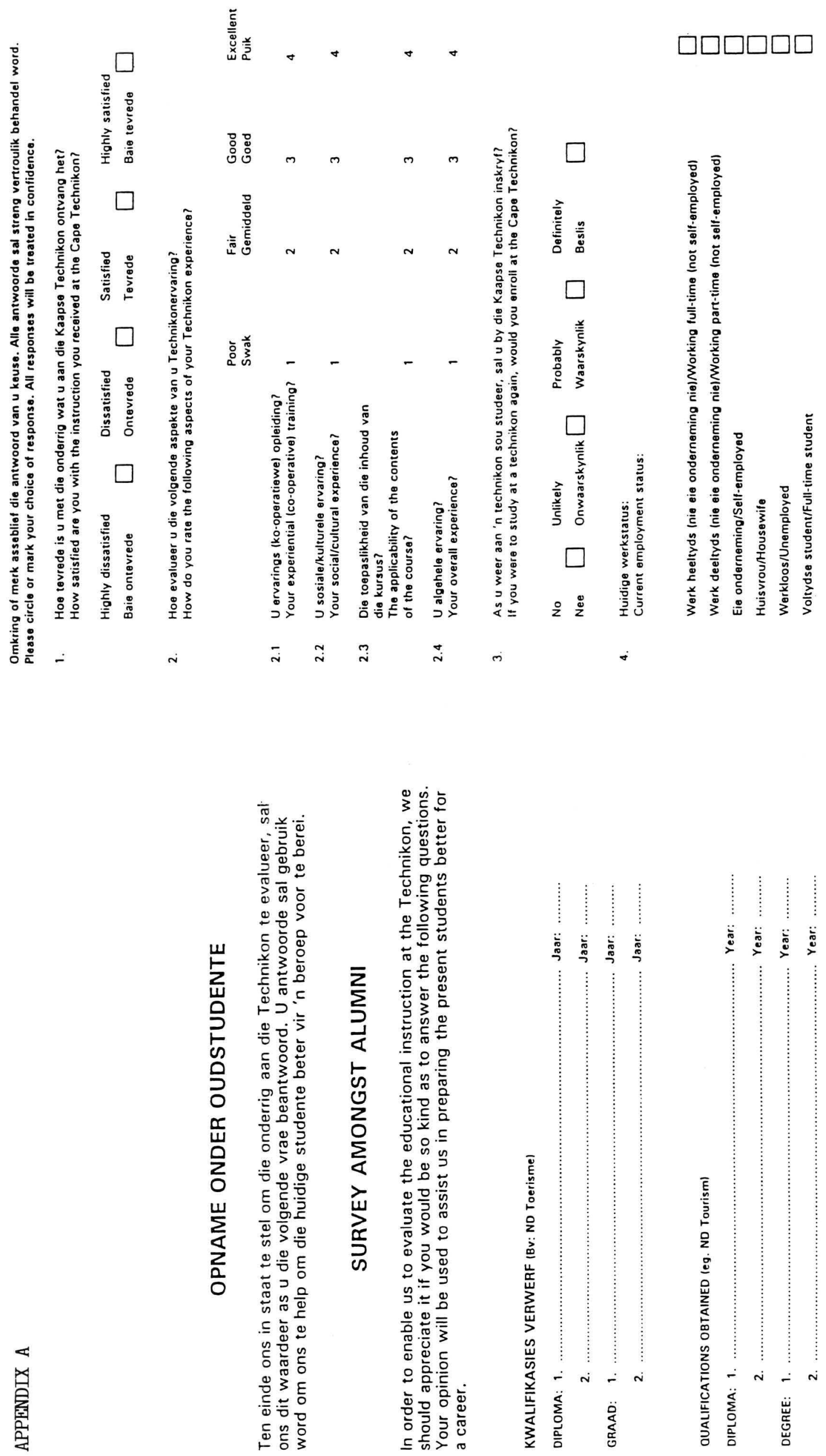

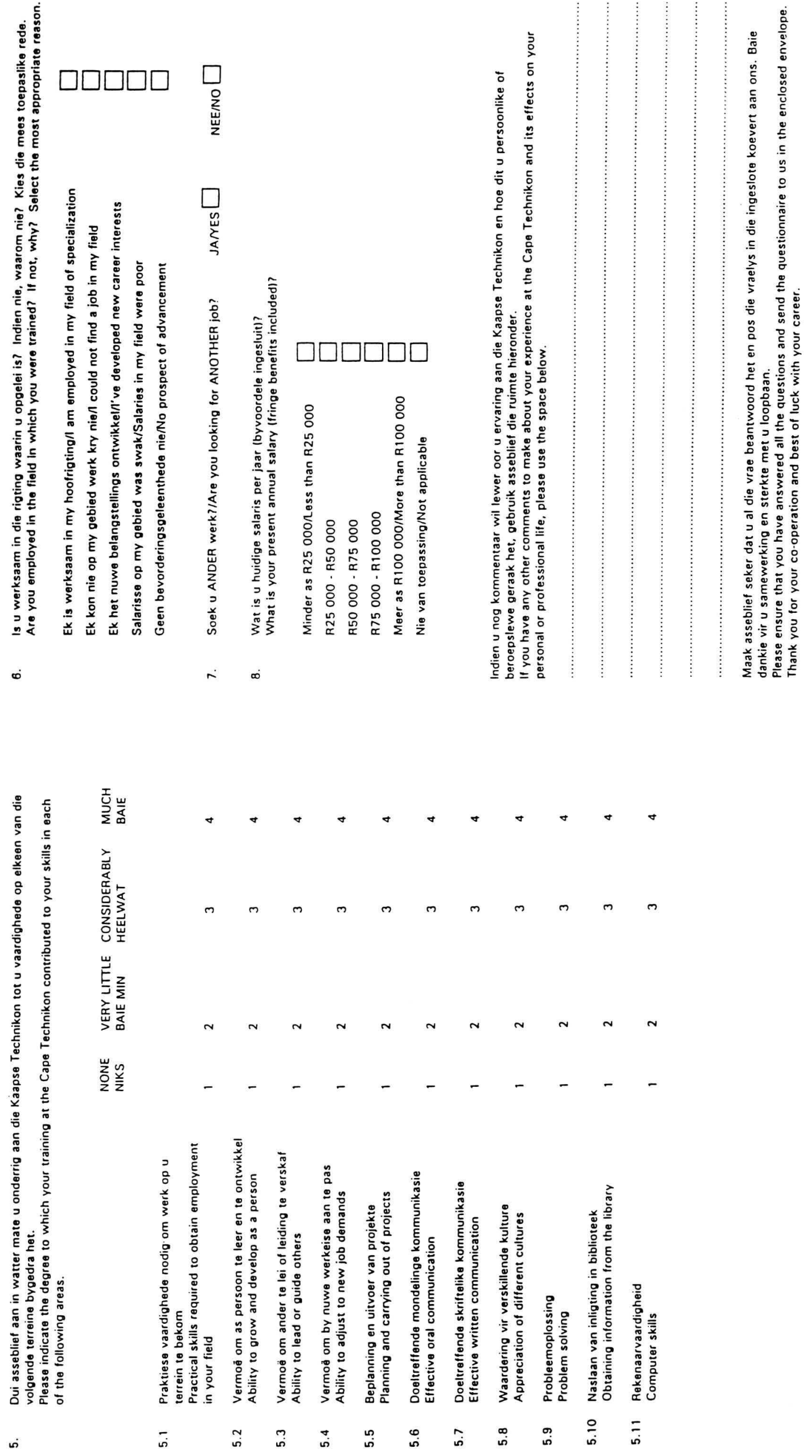